\title{
Analysis of Formulation Strategies on Gas Stove Business Development of Easy Clean with Folding Burner Technology "Best Gas" as a Clean Kitchen Solution
}

\author{
Ismail $^{1}$, Tri Astuti $\mathbf{S}^{2}$, Wardani ${ }^{3}$, Ida Wiwin Arochmawati ${ }^{4}$, Irvan Agustian ${ }^{5}$, \\ Rhian Indradewa ${ }^{6}$, Edi Hamdi ${ }^{7}$, Lis Sintha ${ }^{8}$ \\ 1,2,3,4,5,6,7,8 Master of Management Study Program, Faculty of Economics and Business - Esa Unggul University, \\ Indonesia \\ Corresponding Author: Irvan Agustian
}

DOI: https://doi.org/10.52403/ijrr.20220258

\begin{abstract}
This study aimed to (1) identify internal and external factors that affect the company's business development, (2) analyze internal and external environmental factors that have an impact on the company and the strategic position of PT. Bestindo Jaya Indonesia with the "Best Gas" product as a Clean Kitchen Solutions to compete in the Indonesian stove industry, and (3) determine alternative formulation strategies and priorities that can be recommended for companies in order to achieve company goals. This research is a qualitative method using a questionnaire filled out by the management of PT Bestindo Jaya Indonesia and external parties who are considered experts. This study was a qualitative method using a questionnaire filled out by the management of PT Bestindo Jaya Indonesia and expert external parties. The first stage was identifying internal and external factors through the analysis of the IFE Matrix and the EFE Matrix. The second stage was analyzing the IE Matrix, the Competitive Profile Matrix (CPM) and the SWOT Matrix to assess the factors that affect the company. The last stage was analyzing the QSPM to determine the priorities and alternative strategies that will be prepared by the company as well as formulate the Lean Business Canvas Model. The recommended alternative strategies for PT Bestindo Jaya Indonesia were (1) strengthening product distribution channels, (2) maintaining cost efficiency, and (3) increasing
\end{abstract}

promotion through digital marketing. These three alternative strategies recommendations are expected to be a reference for the management of PT Bestindo Jaya Indonesia to develop the company's business.

Keywords: IE Matrix, Best Gas, Clean Kitchen Solutions, CPM, SWOT Matrix, QSPM.

\section{INTRODUCTION}

In the current era, various household appliances are developed using various technologies to simplify humans to do their household chores. The real evidence of this development is the increasing of stoves with various designs and models. Each stove has different advantages and prices. Manufacturers began to offer product advantages to attract consumers' attention. For example, the use of electric lighter technology which is claimed to ease the use so that it saves gas, besides there is a stove surface using ceflon so it is claimed to ease cleaning, or the use of smart burn technology to save gas and make the fire heat up faster than other stoves (Purwanto et al., 2005).

Based on supply and demand data for gas stoves in 2020, Win Gas products have $8 \%$ market share, Rinnai has $42 \%$ market share, Moderna has 28\% market share, Elextrolux has 14\% market share and 
other gas stove products have $9 \%$ market share are (Kementerian Perisdustrian, 2019). Based on this data, PT Bestindo Jaya Indonesia has a sales target of $3.3 \%$ of Rinnai gas stove products. It can be assumed that the Rinnai gas stove can sell 60 thousand units in a month, so PT Bestindo Jaya Indonesia targets to sell 2 thousand units. On the other hand, the need for household appliances, including gas stoves will increase along with the Indonesia population enhancement. To date, Indonesia is still experiencing a demographic bonus where the growth of productive age population reached $70.2 \%$ of the total population (Kurniawati \& Sugiyanto, 2021). It can encourage an increase in sales of gas stoves in Indonesia (Setiyawan, 2018). Along with intense competition and openness to business opportunities due to the very high productive age population, companies should be able to arrange appropriate business strategies so they can create competitive advantage. Therefore, researchers sought alternative strategies that can be used by PT Bestindo Jaya Indonesia to develop its business.

This study aimed to (1) identify internal and external factors that affect the company's business development, (2) analyze internal and external environmental factors that have an impact on the company and the strategic position of PT. Bestindo Jaya Indonesia with the "Best Gas" product as a Clean Kitchen Solutions to compete in the Indonesian stove industry, and (3) determine alternative formulation strategies and priorities that can be recommended for companies in order to achieve company goals. This study involved the internal management of PT Bestindo Jasa Indonesia and various external parties related to the gas stove business.

\section{LITERATURE REVIEW Strategy Management}

Strategic management is a series of activities and managerial decisions to shape companies' future performance. Companies that can maintain success are usually companies who are always updating themselves with new strategies. If companies do not update themselves, they will be replaced by other aggressive companies (Wheelen, 2018).

This view is similar with Rahim \& Radjab (2016) which state that strategic management describes many rules and activities to achieve company goals and objectives. Based on this view, the researchers concludes that strategic management is an effort to take one or more actions to work with equipment components by determining long-term capabilities so goals and objectives are achieved through the formulation, implementation and consideration of management decisions and actions within an institution.

According to David (2009), the strategy formulation is conducted in three implementation stages, namely the input, the matching, and the decision stage: (1) The first stage is the input stage before the strategy is implemented. Strategic planners should identify and analyze the external environment to identify possible opportunities and threats as well as analyze the internal environment to determine the company's strengths and weaknesses (David, 2009). (2) The second stage is the Matching Stage, namely the IE Matrix and the SWOT Matrix. The IE Matrix describes the company's current position and the SOWT Matrix describes how the external opportunities and threats facing the company appropriated to the company's strengths and weaknesses (Sulistiani, 2018). (3) The third stage is the QSPM Decision Stage using the first level input of analysis and adapting the second level results which provides information for further analysis through the QSPM in the third stage (Mahfud \& Mulyani, 2017). QSPM aims to determine the relative attractiveness of the various selected strategies to determine which strategy is considered to implement. 


\section{Porter's Strategic}

According to David (2009), Porter's five forces model is used in many industries to formulate strategies for companies with different levels of competition. According to Porter (1993), an industry can be seen as a combination of 5 forces: 1) Competition among similar companies; 2) Entry of new competitors; 3) Potential development of substitute products; 4) Bargaining power of suppliers; and 5) Bargaining power of consumers. These five powers are in line with the method practiced by Pawar \& Region (2019) and (Jones et al., 2021) to assess a company's competitive advantage.

\section{SWOT}

SWOT analysis is a systematic process to identify various factors in determining the right formula and playing the best role in the company's strategy (Sulistiani, 2018). Logic-based analysis maximizes strengths and opportunities while minimizing weaknesses and threats. The company's strategic decision-making process is always closely related to the company's vision, mission, goals, strategies and policy development. Therefore, strategic planning needs to analyze SWOT (strengths, weaknesses, opportunities, and threats) in current corporate environment (David, 2009).

\section{RESEARCH METHODOLOGY}

This study was conducted in August - October 2021 at PT Bestindo Jaya Indonesia with the address Cikupa Tangerang area. This study required primary and secondary data from interviews, discussions, and observations of respondents. Additional data was collected through literature review on various published data, financial reports, related information from reports, and other supporting information (Haq \& Indradewa, 2020).

Formulation of alternative competitive strategies and business models development was conducted in several stages (Setiyawati et al., 2021):

\section{Evaluation of External and Internal Factors (EFE and IFE Matrix)}

It explains that external factors are useful for identifying various factors outside the company that affect the company's sustainability. While internal factors are useful for identifying various factors within the company that describe the company's ability to overcome external threats and take advantage of opportunities.

\section{IE Matrix}

The second stage was matching by entering the IFE-EFE results into the Internal External Matrix (IE) to get a more detailed business strategy at the corporate level.

\section{Competitive Profile Matrix (CPM)} Analysis

The CPM matrix is useful for identifying the company's main competitors as well as the strengths and weaknesses of certain competitors regarding the company's strategic position.

\section{SWOT Analysis}

The SWOT matrix is useful for developing company strategy through integration and conformation of the company's strengths and weaknesses with the company opportunities and threats.

\section{QSPM Matrix}

QSPM is useful for choosing the most suitable strategy for the company from various alternative strategies that have been formulated previously.

6. Formulation of Lean Business Canvas Model

It is a summary of the company's business processes when they doing business.

\section{RESULTS AND DISCUSSION \\ Identification of Internal and External Environmental Factors}

PT Bestindo Jaya Indonesia's internal factors included the company's strengths and weaknesses, while external factors included the opportunities and 
threats that will be faced by PT Bestindo Jaya Indonesia.

\section{Internal Success Factor}

Internal Success Factor was the key to internal success that influences the PT Bestindo Jaya Indonesia business development. It had strengths and weaknesses. Strategic internal factors as strengths included: (1) Flat bottom folding burner stove technology without holes that competitors did not have, (2) Strategic warehouse locations that were still available in the Cikupa area, (3) Distributor network in the Gas Stove Industry, (4) Affordable Prices, (5) Ability to procure raw materials (supply chain), (6) Strong marketing network through distributors and use of digital marketing, (7) Simple production process and (8) Brand Patents and Designs. Weakness factors of the company included: (1) brands tended to be new, (2) the lack of experience and human resource capabilities, (3) company-government relation was still in progress, and (4) product was easy to imitate.

\section{External Success Factors}

External factors that affect the business development of PT Bestindo Jaya Indonesia consisted of opportunities and threats. Opportunity factors included: (1) Licensing was online and there was an Online Single Submission (OSS) institution, (2) Open market potential due to the demographic bonus of the population, (3) Competitors for similar products were still limited, (4) Consumers need an elegant and easy-to-clean stove design, (5) people tended to cook at home during a pandemic, (6) the price of similar stoves was still high in the market, (7) there was no folding burner stove technology with a flat surface without holes in the market, (8) digital marketing in the marketplace and social media could facilitate product promotion, (9) Various areas in big cities had service centers that become partners, and (10) There was a distributors network in the Gas Stove industry who can become partners.
Meanwhile, threats that affect PT Bestindo Jaya Indonesia's business development included: (1) Licensing took time and money, (2) In general, people's purchasing power had decreased due to the Covid-19 pandemic, (3) The tendency of the IDR exchange rate to weaken against foreign currencies, especially RMB related to raw material import transactions, (4) Stoves with elegant designs were widely produced by other companies, (5) Millennial, $\mathrm{X}$ and $\mathrm{Z}$ generations tended to switch easily and affected by prices, (6) After-sales service from other brands had been established, (7) Technology and innovation from other competitors, (8) assembly technology was easy to imitate, (9) other brands already exist in the market, and (10) dependency on raw materials from suppliers.

\section{Strategy Factor Evaluation Analysis}

The evaluation of strategic factors consisted of Internal Factor Evaluation (IFE) and External Factor Evaluation (EFE), by rating each internal factor (strengths and weaknesses) and external factors (opportunities and threats).

\section{Internal Factor Evaluation}

The internal factors evaluation results could be seen in Table 1 . The table showed that the highest level of importance on internal factors was the flat bottom folding burner stove technology without holes that competitors did not have, affordable prices and registered Brand and Design Patents with mean of 0.1. While the highest level of importance from the weakness factor namely the brand was still new so consumers or market were not familiar with a mean of 0.1 .

\section{Internal Factor Evaluation Matrix Analysis}

The results of the mean rating value showed that PT BJI had an IFE score of 2.91. This score was above the mean middle point of 2.5. It meant that PT BJI had strong enough internal capability because the 
Ismail et.al. Analysis of formulation strategies on gas stove business development of easy clean with folding burner technology "best gas" as a clean kitchen solution.

highest factors were the strength of product technology and affordability of prices as well as patents on designs and technology.

\section{External Factor Evaluation}

The results of the evaluation of external factors could be seen in Table 2 . The table showed that the external opportunity factor with the highest level was the open market potential due to the demographic bonus of the population and the lack of folding burner stove technology with a flat surface without holes in the market with a mean of 0.07 . Meanwhile, the highest level of importance for threat factor was technology and innovation from other competitors and other previous brands in the market with a mean of 0.07 .

\section{External Factor Evaluation Matrix Analysis}

Table 2 showed that the EFE Matrix analysis score of PT Bestindo Jaya Indonesia for PT BJI's external factors was 3.24 above the mean middle point of 2.5. So, PT BJI will be able to compete well with competitors, take advantage of external opportunities and avoid company threats.

Table 1: Internal Factor Evaluation Matrix

\begin{tabular}{|c|c|c|c|c|}
\hline $\mathbf{A}$ & STRENGTHS & Weight & Rating & Score \\
\hline 1 & The flat bottom folding burner stove technology without holes is not owned by competitors. & 0,10 & 4,00 & 0,40 \\
\hline 2 & Strategic warehouse location is still available in the Cikupa area & 0,08 & 3,00 & 0,24 \\
\hline 3 & There is a distributors network in the Gas Stove Industry & 0,09 & 3,00 & 0,27 \\
\hline 4 & Affordable prices & 0,10 & 4,00 & 0,40 \\
\hline 5 & Ability to procure raw materials (supply chain) & 0,08 & 3,00 & 0,24 \\
\hline 6 & Strong marketing network through distributors and the use of digital marketing & 0,09 & 3,00 & 0,27 \\
\hline 7 & Simple production process & 0,07 & 3,00 & 0,21 \\
\hline 8 & Brand and Design Patents & 0,10 & 4,00 & 0,40 \\
\hline & & & & 2,43 \\
\hline
\end{tabular}

\begin{tabular}{|l|l|l|l|l|}
\hline B & WEAKNESSES & Weight & Rating & Score \\
\hline 1 & Brands tend to be new & 0,10 & 1,00 & 0,10 \\
\hline 2 & Human Resource experiences and capabilities & 0,06 & 2,00 & 0,12 \\
\hline 3 & Relations with the government are still in progress & 0,05 & 2,00 & 0,10 \\
\hline 4 & Products are easy to imitate & 0,08 & 2,00 & 0,16 \\
\hline & & & & 0,48 \\
\hline & & 1,00 & & 2,91 \\
\hline
\end{tabular}

Table 2: External Factor Evaluation Matrix

\begin{tabular}{|c|c|c|c|c|}
\hline $\mathbf{A}$ & OPPORTUNITIES & Weight & Rating & Score \\
\hline 1 & Ease of licensing online and the existence of an Online Single Submission (OSS) institution & 0,04 & 4,00 & 0,16 \\
\hline 2 & The open market potential due to the demographic bonus of the population & 0,07 & 4,00 & 0,28 \\
\hline 3 & Competitors for similar products are still limited & 0,06 & 4,00 & 0,24 \\
\hline 4 & Consumers need stove with elegant designs and easy to clean & 0,05 & 4,00 & 0,20 \\
\hline 5 & People tend to cook at home during a pandemic & 0,05 & 3,00 & 0,15 \\
\hline 6 & The price of similar stoves is still expensive in the market & 0,06 & 4,00 & 0,24 \\
\hline 7 & There is no folding burner stove technology with a flat surface without holes on the market & 0,07 & 4,00 & 0,28 \\
\hline 8 & Digital marketing in marketplaces and social media makes it easy to promote products & 0,06 & 3,00 & 0,18 \\
\hline 9 & Various areas in big cities have service centers that become partners & 0,05 & 3,00 & 0,15 \\
\hline \multirow[t]{2}{*}{10} & There is a distribution network from the Gas Stove Industry which is used as a partner & 0,05 & 3,00 & 0,15 \\
\hline & & & & 2,03 \\
\hline
\end{tabular}

\begin{tabular}{|c|c|c|c|c|}
\hline B & THREATS & Weight & Rating & Score \\
\hline 1 & Licensing takes a lot of time and money & 0,03 & 3,00 & 0,09 \\
\hline 2 & In general, people's purchasing power has decreased due to the COVID-19 pandemic & 0,04 & 3,00 & 0,12 \\
\hline 3 & $\begin{array}{l}\text { The tendency of the IDR exchange rate to weaken against foreign currencies, especially the RMB } \\
\text { related to the import transaction of raw materials }\end{array}$ & 0,05 & 2,00 & 0,10 \\
\hline 4 & Stoves with elegant designs have been produced by other companies & 0,04 & 2,00 & 0,08 \\
\hline 5 & Millennials, $\mathrm{X}$ and $\mathrm{Z}$ generations tend to be easy to switch and sensitive to price & 0,04 & 3,00 & 0,12 \\
\hline 6 & After-sales service from other brands has been established & 0,03 & 4,00 & 0,12 \\
\hline 7 & Other competitor technologies and innovations & 0,06 & 4,00 & 0,24 \\
\hline 8 & Easy-to-copy assembly technology & 0,04 & 3,00 & 0,12 \\
\hline 9 & Other brands are already on the market & 0,06 & 2,00 & 0,12 \\
\hline \multirow[t]{3}{*}{10} & Dependence on raw materials from suppliers & 0,05 & 2,00 & 0,10 \\
\hline & & 1,00 & & 1,21 \\
\hline & & & & 3,24 \\
\hline
\end{tabular}




\section{IE Matrix Analysis}

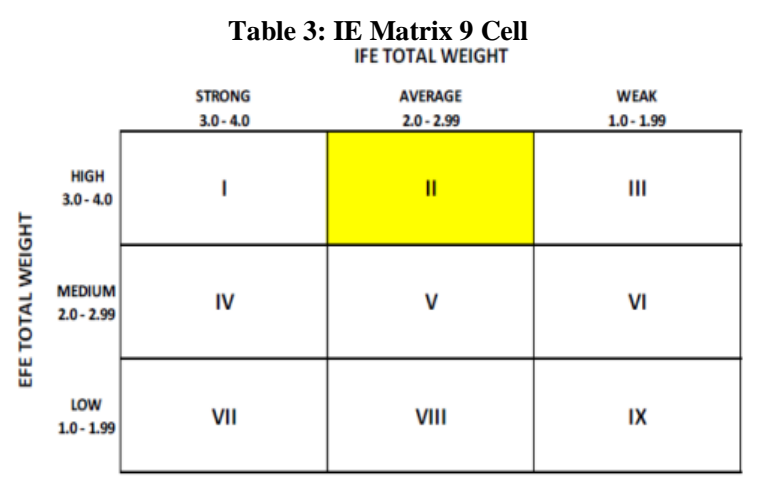

\section{Competitive Profile Matrix Analysis}

The IE matrix was based on the IFE total weight and the EFE total weight. The IE matrix was divided into 3 parts which had different strategic implications. Cells I, II, or IV were companies that were growing and building (grow \& build), cells III, V or VII were companies with a hold and maintain strategy. Cells VI, VIII, or IX were harvest or divest. Based on the matrix above, PT BJI was cell II, namely the grow and build position. There were alternative strategic options, including strengthening product distribution channels, maintaining cost efficiency and increasing promotions through digital marketing.

Competitive Profile Matrix-CPM identified the company's main competitors as well as the strengths and weaknesses of certain competitors regarding the company's strategic position. The total score of PT BJI's analysis was 3.60, which is higher than competitors, especially the items price, quality, display, practicality, technology and after-sales service. It showed that the relative strength of a company will be used to conform and evaluate information as decision making.

Table 4: CPM Matrix

\begin{tabular}{|l|l|l|l|l|l|l|l|l|l|l|}
\hline \multirow{2}{*}{ No } & \multirow{2}{*}{ Critical Success Factor } & \multirow{2}{*}{ Weight } & \multicolumn{2}{l|}{ Best Gas } & \multicolumn{2}{l|}{ Modena } & \multicolumn{2}{l|}{ Rinnai } & \multicolumn{2}{l|}{ Pro Gas } \\
\cline { 3 - 11 } & & & Rating & Score & Rating & Score & Rating & Score & Rating & Score \\
\hline 1 & Quality & 0,20 & 4 & 0,80 & 4 & 0,80 & 4 & 0,80 & 3 & 0,60 \\
\hline 2 & Price & 0,20 & 4 & 0,80 & 2 & 0,40 & 3 & 0,60 & 4 & 0,80 \\
\hline 3 & Display/Design & 0,15 & 4 & 0,60 & 4 & 0,60 & 3 & 0,45 & 3 & 0,45 \\
\hline 4 & Brand Image & 0,15 & 2 & 0,30 & 4 & 0,60 & 4 & 0,60 & 2 & 0,30 \\
\hline 5 & Handy and easy to clean & 0,10 & 4 & 0,40 & 3 & 0,30 & 3 & 0,30 & 3 & 0,30 \\
\hline 6 & Technology & 0,10 & 4 & 0,40 & 4 & 0,40 & 4 & 0,40 & 3 & 0,30 \\
\hline 7 & Product Distribution & 0,05 & 2 & 0,10 & 4 & 0,20 & 4 & 0,20 & 3 & 0,15 \\
\hline 8 & After Sales Service & 0,05 & 4 & 0,20 & 4 & 0,20 & 4 & 0,20 & 3 & 0,15 \\
\hline & & 1,00 & & 3,60 & & 3,50 & & 3,55 & & 3,05 \\
\hline
\end{tabular}

\section{SWOT Matrix Analysis}

SWOT analysis aims to combine SWOT and IE analysis so the coordination of various stages of strategy analysis can stand and avoid significant losses from each strategy (Haq \& Indradewa, 2020). Based on the strengths, weaknesses, opportunities and threats from the SWOT analysis, 15 functional strategies can be formulated, namely 5 combined strategies of strengths and opportunities (SO), 4 combined strategies of weaknesses and opportunities (WO), 4 combined strategies of strengths and threats (ST), and 2 combined strategies of weakness and threat (WT).

Table 5: SWOT Matrix

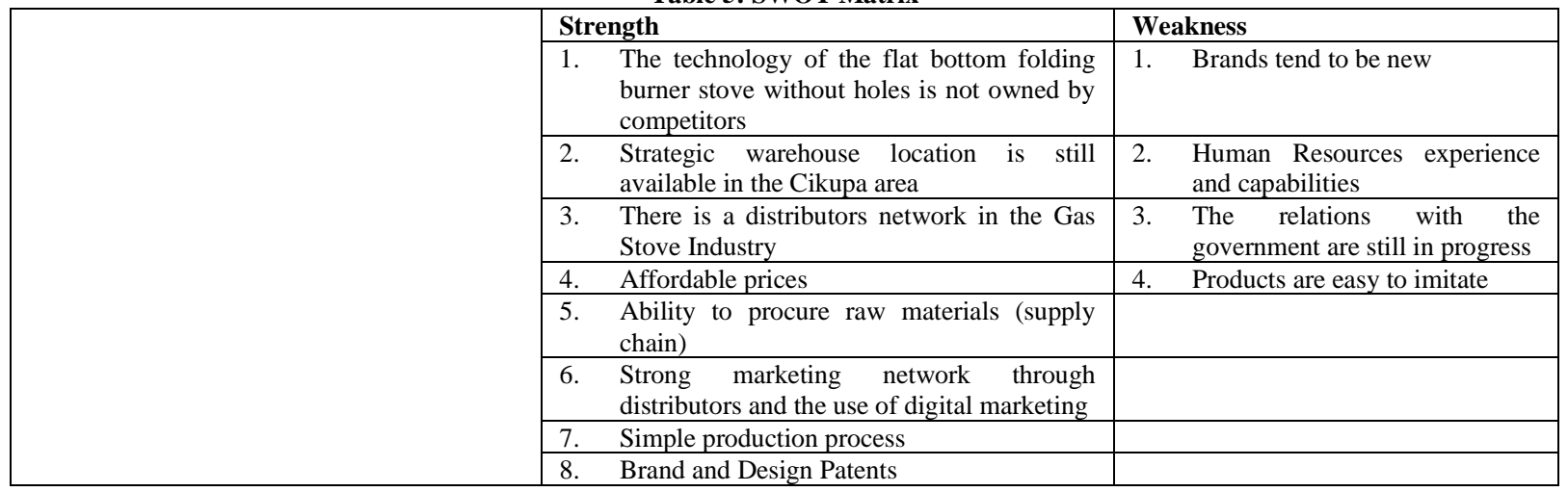


Ismail et.al. Analysis of formulation strategies on gas stove business development of easy clean with folding burner technology "best gas" as a clean kitchen solution.

\begin{tabular}{|c|c|c|}
\hline Opportunity & SO Strategics & WO Strategics \\
\hline $\begin{array}{l}\text { 1. Licensing is online and there is an } \\
\text { Online Single Submission (OSS) } \\
\text { institution }\end{array}$ & $\begin{array}{l}\text { 1. The Best Gas brand and product design (flat } \\
\text { bottom folding burner without holes) are } \\
\text { patented soon }(\mathrm{O} 7, \mathrm{~S} 1, \mathrm{~S} 8)\end{array}$ & $\begin{array}{l}\text { 1. Brand recognition using digital } \\
\text { marketing and social media } \\
\text { (V1, O8) }\end{array}$ \\
\hline $\begin{array}{l}\text { 2. Open market potential due to population } \\
\text { demographic bonus }\end{array}$ & $\begin{array}{l}\text { 2. Cost Efficiency in order to the selling price } \\
\text { can be affordable below competitors' prices } \\
(\mathrm{O} 1, \mathrm{O} 6, \mathrm{~S} 2, \mathrm{~S} 4, \mathrm{~S} 7)\end{array}$ & $\begin{array}{l}\text { 2. Recruit reliable and experienced } \\
\text { workers to support licensing, } \\
\text { production and marketing } \\
\text { processes }(\mathrm{W} 2, \mathrm{~W} 3, \mathrm{O} 1, \mathrm{O} 8)\end{array}$ \\
\hline $\begin{array}{l}\text { 3. Competitors for similar products are } \\
\text { still limited }\end{array}$ & $\begin{array}{l}\text { 3. Increase sales through distributor network } \\
\text { and digital marketing }(\mathrm{O} 2, \mathrm{O} 3, \mathrm{O} 4, \mathrm{O} 5, \mathrm{O} \text {, } \\
\mathrm{O} 8, \mathrm{O} 9, \mathrm{O} 10, \mathrm{~S} 3, \mathrm{~S} 6)\end{array}$ & $\begin{array}{l}\text { 3. Cooperation with expeditions to } \\
\text { speed products distribution to } \\
\text { distributors }(\mathrm{O} 10)\end{array}$ \\
\hline $\begin{array}{l}\text { 4. Consumers need elegant and easy to } \\
\text { clean stove design }\end{array}$ & & \\
\hline $\begin{array}{l}\text { 5. People tend to cook at home during a } \\
\text { pandemic }\end{array}$ & & \\
\hline $\begin{array}{l}\text { 6. The price of similar stoves is still high } \\
\text { in the market }\end{array}$ & & \\
\hline $\begin{array}{l}\text { 7. There is no folding burner technology } \\
\text { with a flat surface without holes on the } \\
\text { market }\end{array}$ & & \\
\hline $\begin{array}{l}\text { 8. } \begin{array}{l}\text { Digital marketing in marketplaces and } \\
\text { social media simplify to promote } \\
\text { products }\end{array} \\
\end{array}$ & & \\
\hline $\begin{array}{l}\text { 9. Various areas in big cities have service } \\
\text { centers that become partners }\end{array}$ & & \\
\hline $\begin{array}{l}\text { 10. There is a distribution network of the } \\
\text { Gas Stove Industry which is a partner }\end{array}$ & & \\
\hline Threat & ST Strategics & WT Strategics \\
\hline 1. Licensing takes a lot of time and money & $\begin{array}{l}\text { I. Increase cooperation with suppliers for the } \\
\text { availability of raw materials (S5, T10) }\end{array}$ & $\begin{array}{l}\text { I. Improving research and } \\
\text { development of innovative } \\
\text { products to excel in the } \\
\text { competition (W4, T4, T7, T8, } \\
\text { T9) }\end{array}$ \\
\hline $\begin{array}{l}\text { 2. In general, people's purchasing power } \\
\text { has decreased due to the COVID-19 } \\
\text { pandemic }\end{array}$ & $\begin{array}{l}\text { 2. Cooperating with service centers in big } \\
\text { cities (S3, T6) }\end{array}$ & $\begin{array}{l}\text { 2. Recruit skilled and experienced } \\
\text { workers to support licensing, } \\
\text { production and marketing } \\
\text { processes }(\mathrm{W} 2, \mathrm{~W} 3, \mathrm{~T} 1)\end{array}$ \\
\hline $\begin{array}{l}\text { 3. The tendency of the IDR exchange rate } \\
\text { to weaken against foreign currencies, } \\
\text { especially the RMB related to the raw } \\
\text { materials import }\end{array}$ & $\begin{array}{l}\text { 3. Cost Efficiency in order to the selling price } \\
\text { can be affordable below competitors' prices } \\
\text { (O1, O6, S2, S4, S7) }\end{array}$ & \\
\hline $\begin{array}{ll}\text { 4. } & \begin{array}{l}\text { Elegant designs stoves are widely } \\
\text { produced by other companies }\end{array} \\
\end{array}$ & & \\
\hline $\begin{array}{l}\text { 5. Millennials, } \mathrm{X} \text { and } \mathrm{Z} \text { generations tend to } \\
\text { be easy to switch and price sensitive }\end{array}$ & & \\
\hline $\begin{array}{l}\text { 6. After-sales service from other brands } \\
\text { has been established }\end{array}$ & & \\
\hline $\begin{array}{l}\text { 7. Technology and innovation from other } \\
\text { competitors }\end{array}$ & & \\
\hline 8. Easy-to-copy assembly technology & & \\
\hline 9. Other brands are already on the market & & \\
\hline $\begin{array}{l}\text { 10. Dependence on raw materials from } \\
\text { suppliers }\end{array}$ & & \\
\hline
\end{tabular}

Furthermore, the SWOT analysis recommendations results were grouped and adapted based on the alternative strategy characteristics (company strategy). Three alternative corporate strategies that can be applied were market development strategies, market penetration strategies, and product development strategies. The three alternative strategies were the most important strategies that companies should implement to develop their businesses.

\section{Strategy Formulation in Developing Company's Business: Quantitative Strategic Planning Matrix}

\begin{tabular}{|l|l|l|l|}
\multicolumn{5}{c}{ Table 6: TAS Alternative Strategy Score } \\
\hline No & Strategy Option & $\begin{array}{l}\text { TAS } \\
\text { Score }\end{array}$ & $\begin{array}{l}\text { Priority } \\
\text { Level }\end{array}$ \\
\hline 1 & $\begin{array}{l}\text { Strengthen product distribution } \\
\text { channels }\end{array}$ & 6.48 & I \\
\hline 2 & Maintain cost-efficiency & 6.37 & II \\
\hline 3 & $\begin{array}{l}\text { Increase promotion through } \\
\text { digital marketing }\end{array}$ & 6.37 & III \\
\hline
\end{tabular}

Quantitative Strategic Planning Matrix or QSPM Analysis is an analytical tool to choose the strategy based on the 
attractiveness of strategic alternatives. The Focus Group Discussion (FGD) analysis results showed that the right strategy with the highest Total Attractiveness Scores-TAS of 6.48 was to strengthen product distribution channels by optimizing the gas stove distributor network in big cities. This strategy could be chosen with the support of other strategies related to cost efficiency and increased promotion. This analysis was strengthened by research conducted by
(Suwarno, 2006) which illustrated that product distribution channels had an important role in increasing product sales in newly established companies.

\section{Lean Business Canvas Model}

The entire business process of PT $\mathrm{BJI}$ related to the assembly and sale of the "Best Gas" glass-bottom gas stove was described in the following lean business canvas model:

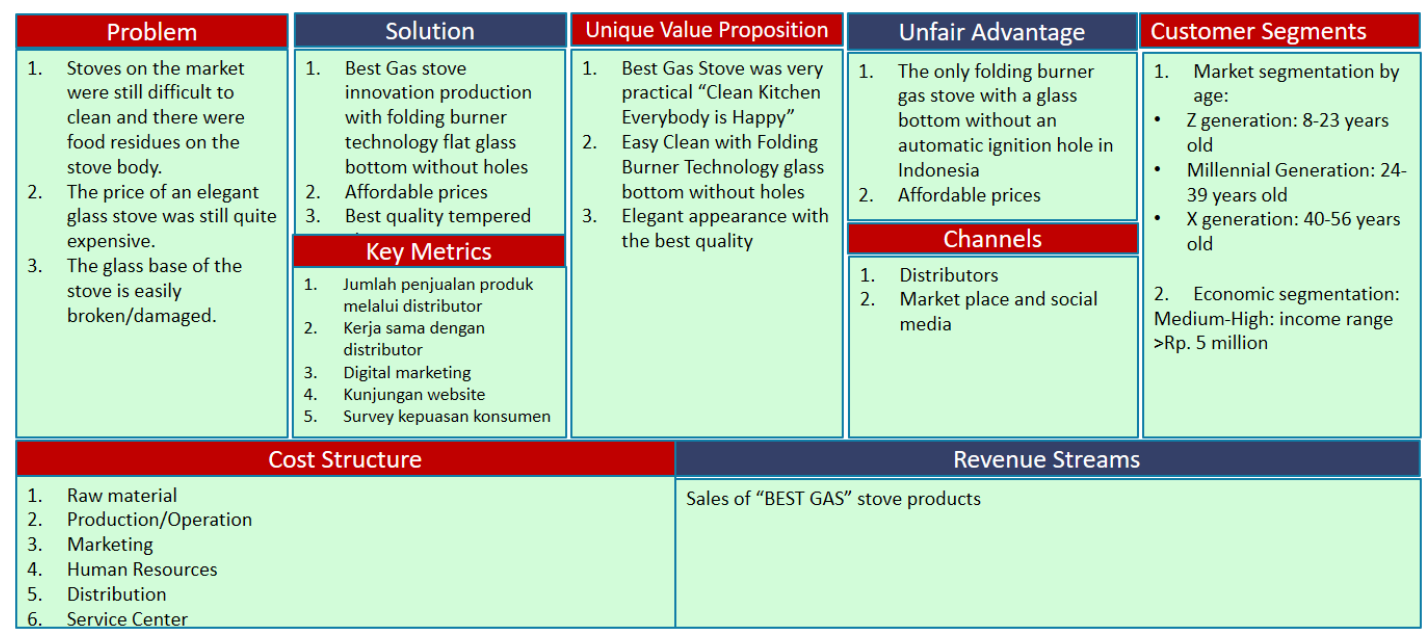

\section{Managerial Implications}

The results of the IE matrix, SWOT matrix and alternative decision-making strategies through QSPM analysis showed that the priority strategies were strengthening product distribution channels, maintaining cost-efficiency, and increasing promotions through digital marketing. The company should implement a strengthening product distribution channels strategy one year in advance. Then, the company should implement a maintaining cost-efficiency strategy in the short to medium term (one to three years). At the same time, the increasing promotion through digital marketing strategy in the medium to long term (the next three to five years). The main objective of these three strategies was to increase business development at PT Bestindo Jaya Indonesia.

\section{CONCLUSION AND SUGGESTIONS Conclusion}

The identification results of the biggest internal strength factors of PT Bestindo Jaya Indonesia are flat bottom folding burner stove technology without holes that competitors do not have, affordable prices and registered Brand and Design Patents. The biggest weakness of PT Bestindo Jaya Indonesia is the new brand so consumers or the market do not know this brand. While the identification results of the biggest external factors of PT Bestindo Jaya Indonesia are the open market potential due to the demographic bonus of the population and the absence of folding burner stove technology with a flat surface without holes in the market. The strongest threat of PT Bestindo Jaya Indonesia is the presence of technology and innovation from other competitors and other brands that are already on the market.

The results of the IE, CPM, SWOT Matrix analysis and the QSPM (Quantitative 
Strategy Planning Matrix) approach recommend to strengthen product distribution channels, maintain costefficiency and increase promotions through digital marketing.

\section{Suggestions}

PT Bestindo Jaya Indonesia can focus on building the good and different distribution channels from its competitors and promote products to the market through collaboration with various market places and other distribution channels assisted by the management of PT Bestindo Jaya Indonesia. So, the market share and consumers of PT Bestindo Jaya Indonesia's Best Gas products can increase and this company find manufacturers of stovemaking materials and suppliers of supporting products to maintain costefficiency. It is an opportunity for PT Bestindo Jaya Indonesia to increase sales due to the support of distribution channels and cost-efficiency savings. Further research on the analysis of the implementing strategies impact on changes in company performance can be conducted further.

\section{Acknowledgement: None}

\section{Conflict of Interest: None}

\section{Source of Funding: None}

\section{REFERENCES}

1. David, F. R. (2009). Strategic Management CONCEPTS AND CASES.

2. DU Haq, Harianto, R Indradewa (2020). Strategic Formulation Analysis of Virtual Gas Pipeline Business Development (CNG $\& L N G)$. International Journal of research and review, 7 (12), 57-65

3. ME Jones, A Wulandari, Ubaidillah, IW Rinumpaka, R Indradewa (2021). Strategic Formulation Analysis of Semi-Permanent Building Provider from Containers, " $I$ Cont". International Journal of Research and Review 8 (11), 431-440

4. Kurniawati, E., \& Sugiyanto, C. (2021). Pengaruh Struktur Umur Penduduk terhadap Pertumbuhan Ekonomi di Indonesia The E ff ect of Population Age
Structure on Economic Growth in Indonesia Pendahuluan. 21(1), 41-58.

5. Mahfud, T., \& Mulyani, Y. (2017). Aplikasi Metode QSPM ( Quantitative Strategic Planning Matrix) ( Studi Kasus : Strategi Peningkatan Mutu Lulusan Program Studi Tata Boga) agar mampu bersaing dengan Negara lain . Berdasarkan dari Human Development ( HDI ) yang dilakukan oleh UNDP pada tahun Daya Manusia ( SDM ). Indonesia sebagai pengetahuan dan kualitas tenaga kerjanya dan sumberdaya manusia khususnya mahasiswa Program Studi Tata Boga agar dapat menjadi lulusan yang terampil dalam bidangnya . 1(1).

6. Pawar, S., \& Region, K. (2019). Porter 's Five Forces Model: Gives You A Competitive Advantage. 11, 1436-1448.

7. Perisdustrian, K. (2019). Jadikan Indonesia Sebagai Pusat Produksi Kompor Gas. Media Industri, 24.

8. Porter, ME. 2008. Competitive Advantage (Keunggulan Bersaing): Menciptakan dan Mempertahankan Kinerja Unggul. Tangerang (ID): Kharisma Publishing.

9. Purwanto, W. W., Basuki, A. S., \& Rahmayani, S. nlN. (2005). Perancangan Burner untuk Meningkatkan Kinerja Pembakaran Kompor Gas. Reactor, 9, 6772.

https://www.researchgate.net/publication/31 7681714_perancangan_Burner_Untuk_Men ingkatkan_Kinerja_Pembakaran_Kompor_ Gas_LPG

10. Rahim, H. A. R., \& Radjab, E. (2016). Manajemen strategi. Lembaga Perpustakaan dan Penerbitan Universitas Muhammadiyah Makassar.

11. Setiyawan, F. C. (2018). Perancangan Ulang Kompor Gas Dua Tungku Dengan Menggunakan Metode Design For Assembly (DFA) [Universitas Muhammadiyah Surakarta]. http://eprints.ums.ac.id/61745/1/NASKAH PUBLIKASI.pdf

12. E Setiyawati, A Saputra, R Indradewa, TYR Syah (2021). Strategic Formulation Analysis to Build a New Business Startup “ Jamu Partnership " in Indonesia. International Journal of Research and Review 8 (8), 568-576

13. Sulistiani, D. (2018). Analisis SWOT sebagai Strategi Perusahaan dalam Memenangkan Strategi Bisnis. Manajemen Bisnis, 1(1). 
Ismail et.al. Analysis of formulation strategies on gas stove business development of easy clean with folding burner technology "best gas" as a clean kitchen solution.

14. Suwarno, H. L. (2006). Sembilan Fungsi Saluran Distribusi: Kunci Pelaksanaan Kegiatan. 6(1), 79-87.

15. Wheelen, T. L. (2018). Concepts in Strategic Management and Business Policy Concepts in Strategic Management and Business Policy.
How to cite this article: Ismail, Tri Astuti S, Wardani et.al. Analysis of formulation strategies on gas stove business development of easy clean with folding burner technology "best gas" as a clean kitchen solution. International Journal of Research and Review. 2022; 9(2): 458-467. DOI: https://doi.org/10.52403/ijrr.20220258 